\title{
Customer Acceptance Analysis of Customer Relationship Management (CRM) Systems in Automotive Company using Technology Acceptance Model (TAM) 2
}

\author{
S C W Ngangi ${ }^{* 1}$, A J Santoso ${ }^{2}$ \\ ${ }^{1,2}$ Faculty of Informatics Engineering, Universitas Atma Jaya Yogyakarta, Yogyakarta, \\ Indonesia 55281
}

E-mail: stephano.ngangi@gmail.com ${ }^{* 1}$, albjoko@staff.uajy.ac.id ${ }^{2}$

Masuk: 16 Februari 2019, direvisi: 24 Februari 2019, diterima: 27 Februari 2019

\begin{abstract}
Abstrak. Persaingan bisnis dalam era teknologi membutuhkan kreativitas dan inovasi untuk menciptakan perusahaan yang sukses. Customer Relationship Management (CRM) adalah sistem yang bertujuan antara lain, untuk memberikan peningkatan hubungan antara perusahaan dan pelanggan, sehingga terjadi realisasi informasi terintegrasi yang digunakan untuk menghasilkan layanan yang optimal. Selain itu dapat diperoleh informasi tentang pelanggan sehingga kebutuhan pelanggan dapat terpenuhi dan menambah kesetiaan pelanggan. Selain itu, CRM dapat bermanfaat untuk meningkatkan efisiensi dan mengurangi biaya operasional PT. Hasjrat Abadi (Cabang Tendean). Untuk mendukung kesuksesan PT. Hasjrat Abadi (Cabang Tendean), penelitian ini akan memeriksa sistem CRM untuk diterapkan pada PT. Hasjrat Abadi (Cabang Tendean) dengan mengintegrasikannya ke dalam Model Technology Acceptance Model (TAM) sebagai model yang dapat dianalisis dan dipahami sehingga nantinya dapat mempengaruhi pelanggan dalam penggunaan teknologi sebagai sistem informasi dengan menggunakan variabel sistem informasi. Dalam penelitian ini, telah ditinjau penerimaan pengguna berdasarkan 4 variabel dalam TAM itu sendiri. PT. Hasjrat Abadi (Cabang Tendean) memiliki masalah di mana masih ada kekurangan permintaan pelanggan untuk produk TOYOTA. Oleh karena itu, implementasi sistem TAM untuk CRM akan diupayakan sehingga dapat mengidentifikasi pelanggan PT. Hasjrat Abadi (Cabang Tendean Manado) yang ingin membeli produk dari PT Hasjrat Abadi (Cabang Tendean) Manado dan meningkatkan nilai jual produk.
\end{abstract}

Kata kunci: Technology Acceptance Model (TAM); Customer Relationship Management (CRM); pelanggan; perusahaan; teknologi

Abstract. The technological era in business competition requires creativity and innovation to create a successful company. CRM (Customer Relationship Management) is a system that aims, among others, to provide improving relations between the company and customers, so that the realization of integrated information is used to produce optimal services and obtain useful customer information so that customer needs can be met and encouraged to loyalty. In addition, CRM can be useful to improve efficiency and reduce operational costs of PT. Hasjrat Abadi (Tendean Branch). To support the success of PT. Hasjrat Abadi (Tendean Branch), this study will examine a CRM system to be applied to PT. Hasjrat Abadi (Tendean Branch) by integrating it into the Technology Acceptance Model (TAM) as a model that can be analyzed and understood so that later it can influence customers in the use of technology as an 
information system by using informational system variables. In this research, user acceptance has been reviewed based on 4 variables in TAM itself. PT. Hasjrat Abadi (Tendean Branch) has a problem where there is still a lack of customer demand for TOYOTA products. Therefore, the implementation of the TAM system for CRM will be pursued so that it can identify the customers of PT. Hasjrat Abadi (Tendean Branch) Manado who want to buy products from PT Hasjrat Abadi (Tendean Branch) Manado, and increase the selling value of the product.

Keywords: Technology Acceptance Model (TAM); Customer Relationship Management (CRM); customer; company; technology

\section{Introduction}

Technological advancement in the modern age has caused many corporations and business organizations to use information technology and innovation as a method to improve their marketing techniques. Five decades ago, customer satisfaction was the top priority for every action performed by a business in a general sense. This has been confirmed multiple times by [1], [2], [3], and [4] and in the following decade Levitt and other researchers agree with the critical importance of customercentric business practices [5]. Businesses also use various systems and strategies in sales known as Customer Relationship Management (CRM). Through this method, it becomes possible to see customer satisfaction levels, whether through stakeholders and/or shareholders [6]. In other words, companies that use CRM can instill a connection between company and customer, as well as cooperation in an open and tight-knit manner between the two parties [7].

PT. Hasjrat Abadi (Tendean branch) is a large and well-known joint stock company that focuses in the automotive industry and the sale of spare parts that has officially received recognition from the Indonesian government as the sole proprietor in the sale of Toyota automobiles in Manado since 2010. The company is also a giant in repairing and the selling of accessories for Toyota vehicles with the purpose of increasing customer interest and satisfaction. With the arrival of fierce competition in the automotive industry, Hasjrat Abadi (Tendean Branch) needs to increase sales and quality of services offered to customers [8]. In order to achieve this, the company needs to tend to every wish and need of their customers through the use of CRM in an indirect manner. This is aimed to give satisfaction to customers in a comprehensive manner as well as providing services according to the needs of their customers.

In consideration to the background stated above, research was done about the acceptance of services provided to customers by the company using the Technology Acceptance Model (TAM) system and then admitted into the Customer Relationship Management system to output new CRM factors such as Trust, Brand Loyalty, Co-creation and Empowerment. These factors will be used to acquire information on the needs of customers and to make decisions accurately based on these needs to help raise customer loyalty and make Hasjrat Abadi a trusted, well-received company with abundant long-term business relations with other companies.

The goal of this study is to measure the perception and acceptance of services provided by the company to the customer as well as to measure other factors such as usefulness and ease of use, in order to find out the factors that decide customer satisfaction. Another goal is also to find out any future needs of the customers.

\section{Theoretical Framework}

\subsection{Customer Relationship Management (CRM)}

CRM is similar method used by a company for maintaining relations with their customers, using methods such as telephone calls, email, websites, as well as marketing. In other words, Customer Relationship Management is the application of information technology (also known as IT) in a company's marketing department [9].

Ngangi, Santoso (Customer Acceptance Analysis of Customer Relationship Management (CRM) Systems in Automotive Company using Technology Acceptance Model (TAM) 2) 
CRM is the primary tool for sustained long-term growth and profits for a company through the development of customer satisfaction [10]. Other than that, this software is also a system that allows a company to give effective services to the customer. Figure 1 shows an image of the CRM system in a business.

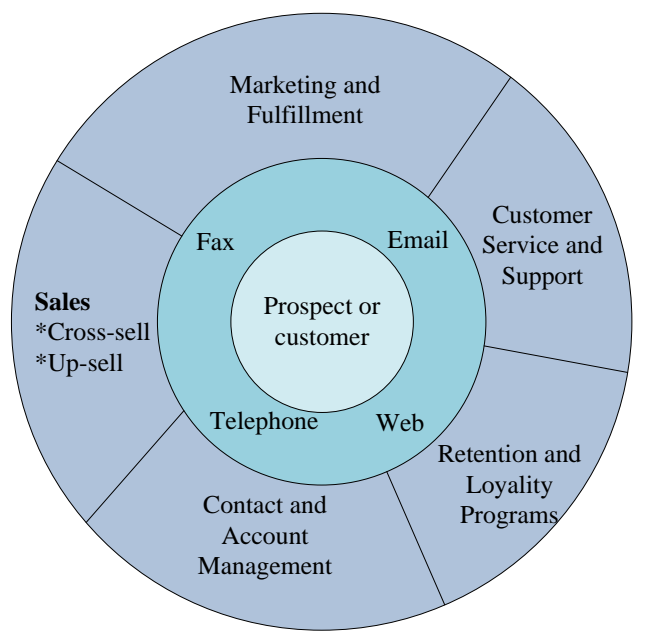

Figure 1. CRM system business process [10]

From figure 1, it can be stated that the business process is a collection of activities that are made to address a particular strategic goal for a company. Kenneth states that the business process has various characteristics such as [11]:

1. A clear goal.

2. A defined input and output.

3. Uses resources.

4. Has a process with a precise structure/order.

5. Can affect more than one unit within a company.

6. Can create new beliefs and values for customers, whether internal or external. Applications that apply CRM can be divided into 3 components [12] as follows:

1. Operation CRM

Operational CRM is an application that is related to good processes in a business, services, marketing and sales, including customer touch point, customer channels, and front office-back office.

2. Analytical CRM

Analytical CRM allows a company to procure data about customer opinion though analysis and make interpretations of the data about sales and/or customers.

3. Collaborative CRM

This is type of CRM that uses e-mail, e-communities, forum discussions and other tools to analyze data to make decisions about services or customer satisfaction.

\subsection{Technology Acceptance Model (TAM)}

TAM that first introduced by Davis [13] is an advancement from the TRA model that was researched by Fishbein and Ajzen [14]. The TAM model focuses on the psychological analysis of customers. The TAM model is based on customer experiences toward implemented technology [15]. The core of TAM is based on 2 variables such as perceived usefulness and perceived ease of use, with 2 endogenous factors called Behavioral Intention (BI) and Actual system Use (AU) [15]. TAM has experienced multiple changes with theoretical developments about acceptance models [15]. TAM 3 shown in figure 2 is an updated TAM with various added constructs.

Ngangi, Santoso (Customer Acceptance Analysis of Customer Relationship Management (CRM) Systems in Automotive Company using Technology Acceptance Model (TAM) 2) 


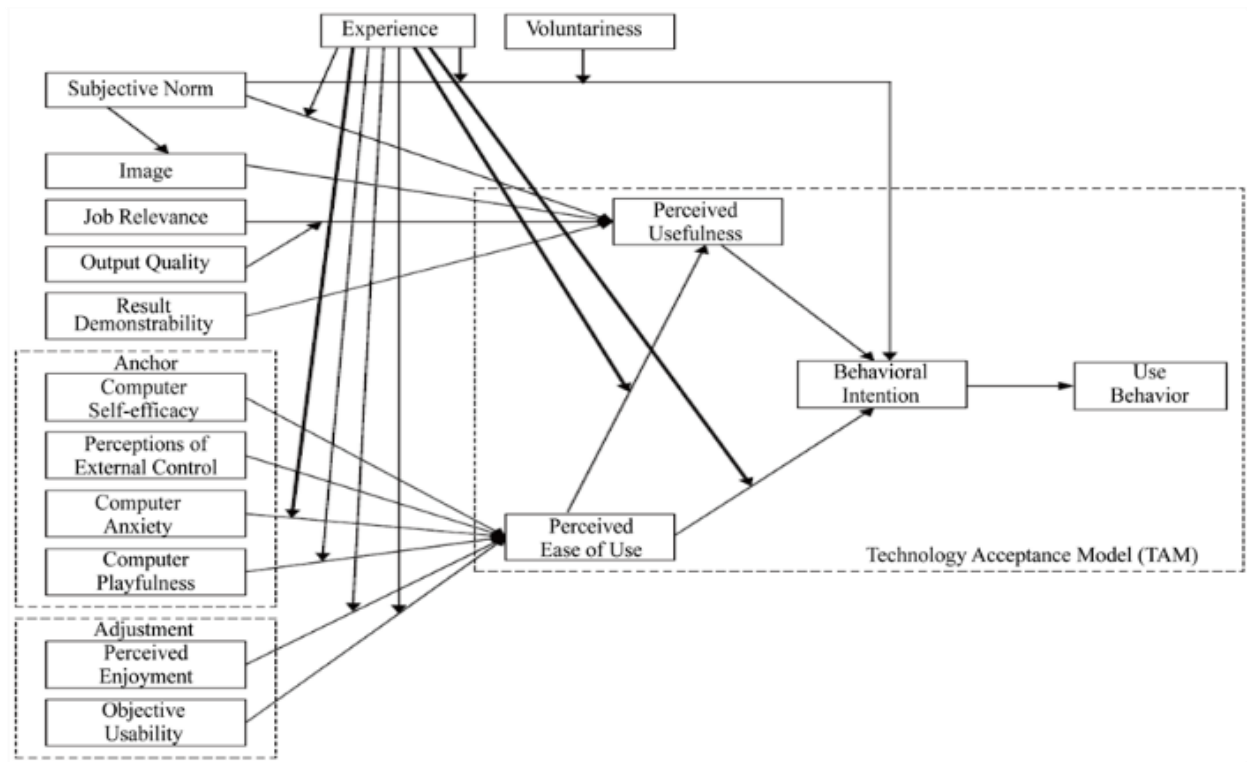

Figure 2. Technology Acceptance Model 3 (TAM 3)

\section{Research Methodology}

The research instrument used in collecting data is a questionnaire. The questionnaire contains several questions distributed to respondents. The type of question is closed-end questions which means that the respondent have to choose one of the answers provided in the questionnaire. Then the respondent's qualitative answers which has been measured based on the Likert scale.

The population of this research is the customers of PT. Hasjrat Abadi (Tendean Branch), with the number of samples using the Maximum Likelihood Estimation (MLE) procedure 100-200 samples [16]. In this case 200 respondents as samples were taken. The sampling technique uses Simple Random Sampling, namely samples taken and made randomly without regards to the strata [17]. To measure acceptance in this study, we use TAM 2 model that has passed prestudy to receive the correct models and variables. TAM 2 model can be seen in figure 3 .

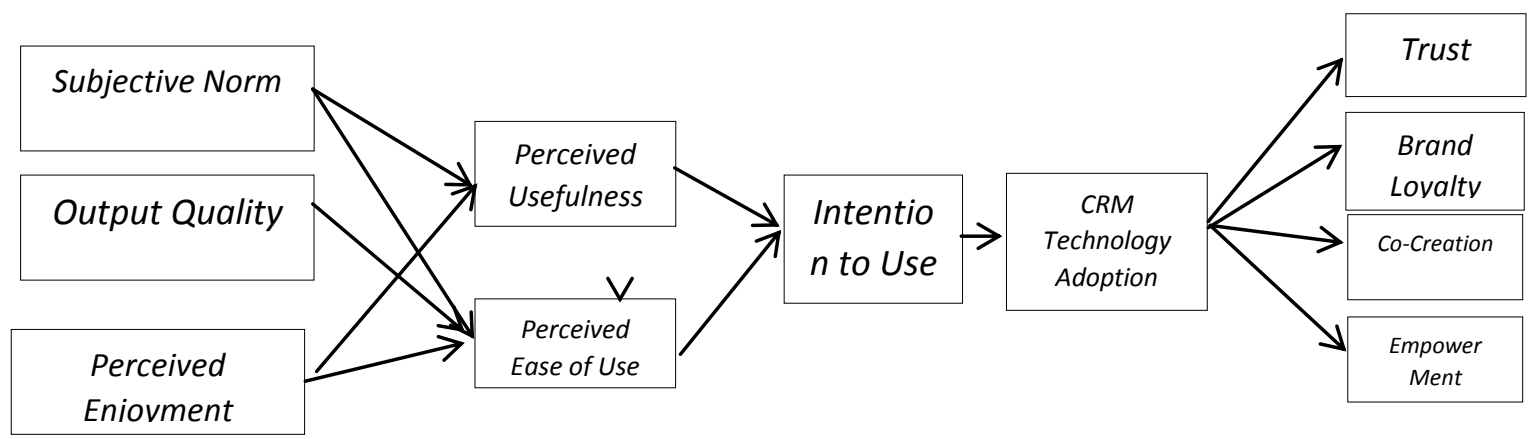

Figure 3. TAM 2 as a study model

TAM can be used for customers' wishes in the Hasjrat Abadi company (Tendean Branch) based upon these variables:

1. Subjective Norm

It can be some of perceived social pressure so it can perform or not perform for the behaviour [15]. 
2. Output Quality

Output quality explains that development is required to earn further quality [18]. To measure the quality of statistical output is with the right quality for each product provided and the usefulness of this product.

3. Perceived Enjoyment

How much the services bring enjoyment to the user, whether the user feels comfortable or not. If the user does not feel comfortable, there will be consequences towards the users' productivity. If the user feels happy, they will continue to use the service [19].

4. Perceived Usefulness

According to Davis, at the perception about use is based upon how a person can believe that the usefulness of some technology can be improved for a work management [15].

5. Perceived Ease of Use

The scale that a person believe some of particular system can be free from the effort.

6. Intention to Use

It is some kind of will of a customer to use a new categories [15].

Following the TAM models above, hypotheses for this research are stated below:

H1: Subjective Norm (SN) has an influence on Perceived Usefulness (PU).

H2: Subjective Norm (SN) has an influence on Perceived Ease of Use (PEU).

H3: Output Quality (OQ) has an influence on Perceived Ease of Use (PEU).

H4: Perceived Enjoyment (PE) has an influence on Perceived Usefulness (PU).

H5: Perceived Enjoyment (PE) has an influence on Perceived Ease of Use (PEU).

H6: Perceived Ease of Use (PEU) has an influence on Perceived Usefulness (PU).

H7: Perceived Usefulness (PU) has an influence on the Intention to Use (ITU).

H8: Perceived Ease of Use (PEU) has an influence on the Intention to Use (ITU).

H9: Intention to Use (ITU) has an influence on CRM Technology Adoption.

\section{Results and Discussion}

\subsection{Questionnaire validity and reliability}

The validity of data collected by the researcher is tested with Structural Equation Modeling (SEM). This technique uses confirmatory factor analysis with the AMOS 22.0. Program reliability testing on this research uses the Construct Reliability technique (CR) and Average Variance Extracted (AVE). Variables of CR $>0,70$ and AVE $>0,5$, that can be seen in table 1 .

Table 1. Validity and Reliability Test Results

\begin{tabular}{|c|c|c|c|c|}
\hline Variable & Point & $\begin{array}{c}\text { Factor } \\
\text { Loading }\end{array}$ & $\begin{array}{l}\text { Component } \\
\text { Reliability }\end{array}$ & AVE \\
\hline \multirow[t]{5}{*}{ SN } & SN1 & 0,830 & \multirow{5}{*}{0.8966} & \multirow{5}{*}{0.6346} \\
\hline & $\mathrm{SN} 2$ & 0,785 & & \\
\hline & SN3 & 0,807 & & \\
\hline & SN4 & 0,778 & & \\
\hline & SN5 & 0,782 & & \\
\hline \multirow[t]{2}{*}{ OQ } & OQ1 & 0,781 & \multirow{2}{*}{0.8750} & \multirow{2}{*}{0.6370} \\
\hline & OQ2 & 0,745 & & \\
\hline
\end{tabular}

Ngangi, Santoso (Customer Acceptance Analysis of Customer Relationship Management (CRM) Systems in Automotive Company using Technology Acceptance Model (TAM) 2) 


\begin{tabular}{|c|c|c|c|c|}
\hline Variable & Point & $\begin{array}{c}\text { Factor } \\
\text { Loading }\end{array}$ & $\begin{array}{c}\text { Component } \\
\text { Reliability }\end{array}$ & AVE \\
\hline \multirow{5}{*}{$\mathbf{P E}$} & OQ3 & 0,799 & \multirow{7}{*}{0.9322} & \\
\hline & OQ4 & 0,863 & & \\
\hline & PE1 & 0,881 & & \multirow{5}{*}{0.7335} \\
\hline & PE2 & 0,873 & & \\
\hline & PE3 & 0,824 & & \\
\hline \multirow{5}{*}{ PU } & PE4 & 0,836 & & \\
\hline & PE5 & 0,867 & & \\
\hline & PU1 & 0,881 & \multirow{4}{*}{0.9352} & \multirow{4}{*}{0.7832} \\
\hline & PU2 & 0,889 & & \\
\hline & PU3 & 0,886 & & \\
\hline \multirow{4}{*}{ PEU } & PU4 & 0,884 & & \\
\hline & PEU1 & 0,770 & \multirow{4}{*}{0.8815} & \multirow{4}{*}{0.6507} \\
\hline & PEU2 & 0,796 & & \\
\hline & PEU3 & 0,818 & & \\
\hline \multirow{3}{*}{ ITU } & PEU4 & 0,841 & & \\
\hline & ITU1 & 0,761 & \multirow{5}{*}{0.9042} & \multirow{5}{*}{0.6540} \\
\hline & ITU2 & 0,847 & & \\
\hline \multirow{7}{*}{ TA } & ITU3 & 0,809 & & \\
\hline & ITU4 & 0,829 & & \\
\hline & ITU5 & 0,795 & & \\
\hline & TA1 & 0,740 & \multirow{4}{*}{0.8397} & \multirow{4}{*}{0.5671} \\
\hline & TA2 & 0,746 & & \\
\hline & TA3 & 0,776 & & \\
\hline & TA4 & 0,750 & & \\
\hline
\end{tabular}

In the validity test, the data used came from AMOS version 22.0 from all sample questions that involved each variable to be processed in this study. Ghozali said that the data were declared valid if the value of a factor variable reached more than 0.5 , or $>0.5$. Based on the validity test research, it is argued that all question indicators representing the seven variables above can be stated true or valid if they have values above 0.5 [20].

Ghozali also concluded that if the test results are said to be true or can be used if the values obtained from construct reliability are worth more than 0.7 or $>0.7$ and average variance extracted has a value of more than 0.5 or $>0.5$ [20]. The results of this test indicate that the values of CR and AVE 
on the variables have exceeded the specified value limit. Based on the results stated, it can be concluded that the entire research data used are reliable so that the research can proceed.

\subsection{SEM Data Analysis}

Based on the research model described above, the instrument for data analysis employing SEM and analysis instrument using the AMOS application. The first step is to create a path diagram as the research framework. AMOS has been developed to have drawing arrangements on flowcharts so that the AMOS method can be used accurately. Flowchart used in this research shown in figure 4.

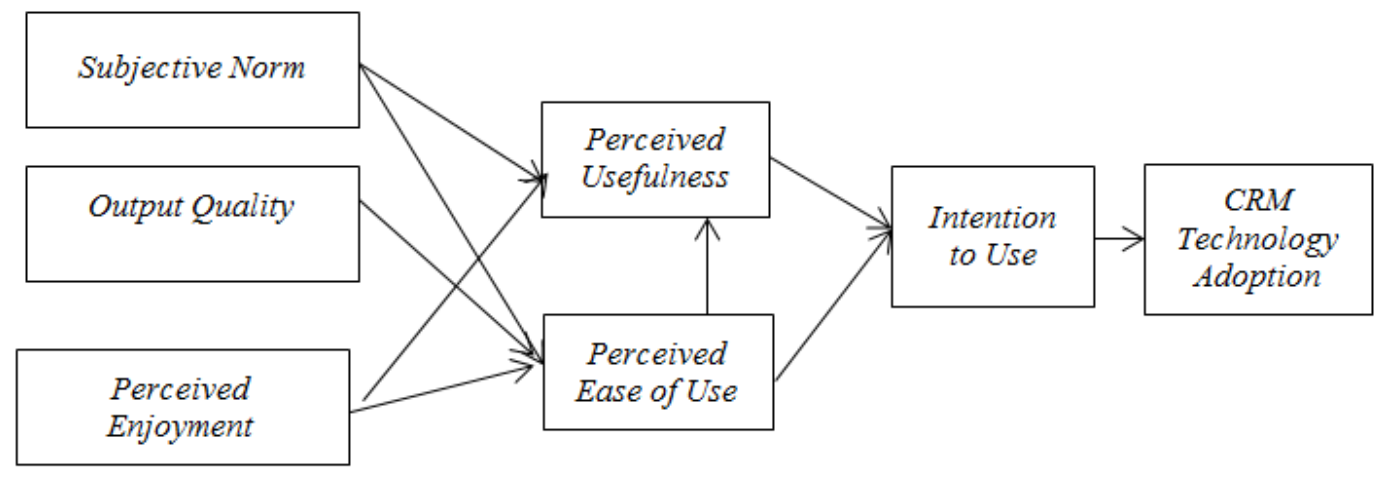

Figure 4. Flowchart

Next, converting a flowchart into an equation by carrying out either structural equations or equations in model measurements. Figure 5 shows Full Model SEM in this research.

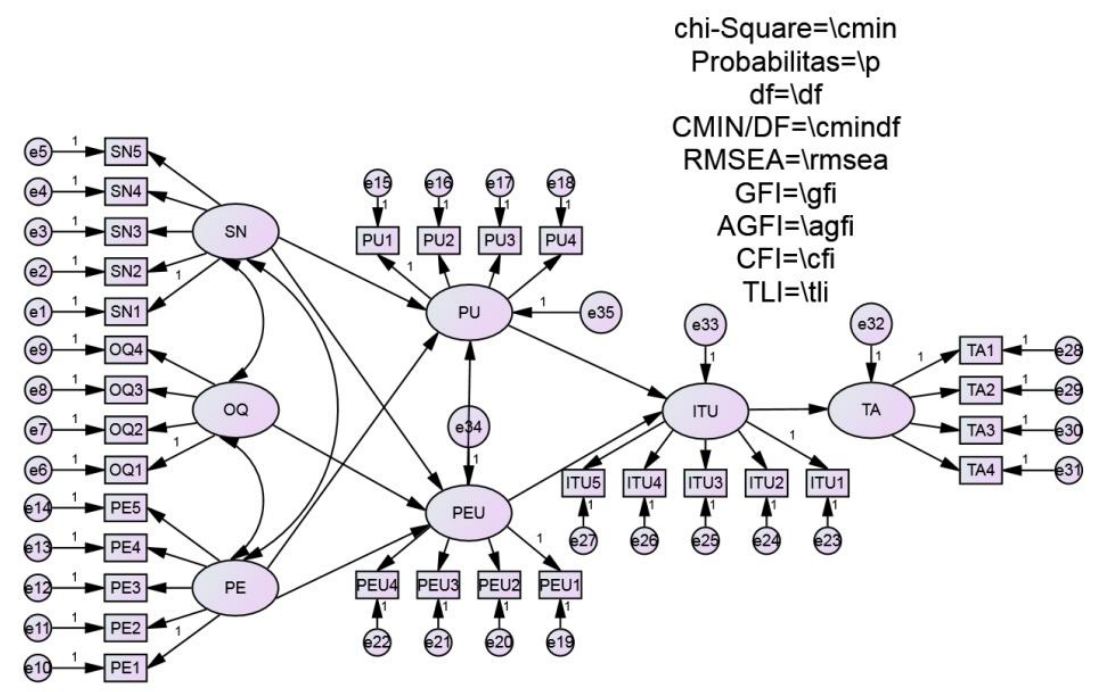

Figure 5. Full Model SEM

According to [20], if the model does not fit, modifications can be made to the model by adding and removing the connecting lines of the model. Modifications are made to achieve better results, such as decreasing the Chi-square values, raising values of probability, GFI, TLI, CFI, AGFI and other to get a model that fits well and supports the research. The new model can be seen in figure 7 . 


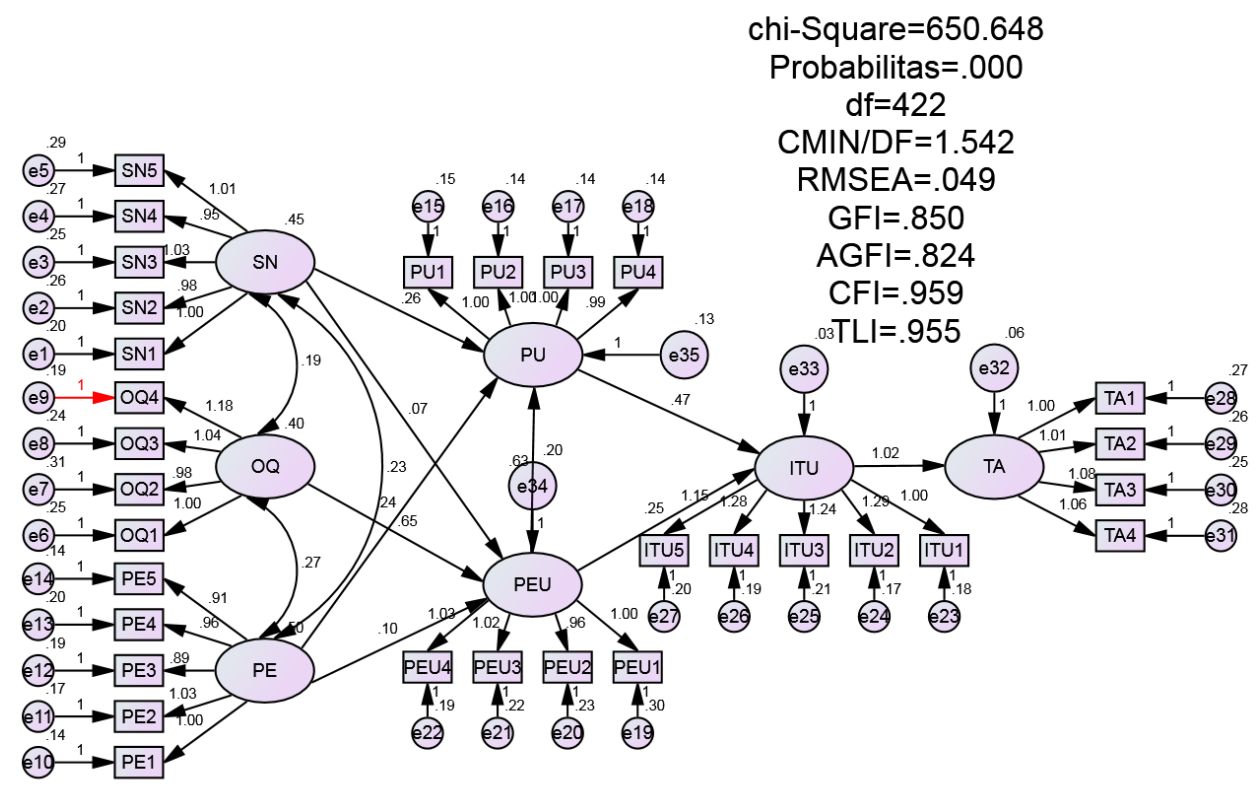

Figure 6. Initial Diagram Model

The SEM assumption was made and the output was in accordance with figure 6 , the next step is to check the data using suitability variables in the measurement of models that will later be examined. The index can be seen in table 2 .

Table 2. Good Fit Value Index Test

\begin{tabular}{cccc}
\hline $\begin{array}{c}\text { A goodness of fit } \\
\text { index }\end{array}$ & Cut-off value & Research Model & Model \\
\hline RMSEA & $\leq 0.08$ & 0,049 & Good Fit \\
CMIN/DF & $\leq 2.0$ & 1,542 & Good Fit \\
AGFI & $\geq 0.80$ & 0,824 & Good Fit \\
GFI & $\geq 0.90$ & 0,850 & Marginal Fit \\
TLI & $\geq 0.90$ & 0,955 & Good Fit \\
CFI & $\geq 0.90$ & 0,959 & Good Fit \\
Significant probability & $\geq 0.05$ & 0,000 & Marginal Fit \\
\hline
\end{tabular}

It can be concluded from table 2 that the overall model displays the results of different levels of conformity, not all of which produce good value. Then the test results of the goodness of fit based on the table above can be used because it has been observed that it is not fully similar to the theory or model.

\subsection{Examination}

The next step in examining the hypothesis is in the form of questions towards this research by examining the structural relationships from a model. The data hypothesis can be seen through regression weight that shows the effect of coefficient between variables in table 3 . 
Table 3. Hypothesis Results

\begin{tabular}{clccccc}
\hline No & \multicolumn{1}{c}{ Hypothesis } & Estimate & c.r. & P & Limit & Explanation \\
\hline 1 & $\begin{array}{l}\text { Subjective Norm (SN) has an } \\
\text { influence on Perceived Usefulness } \\
\text { (PU) }\end{array}$ & 0,256 & 4,501 & 0,000 & 0,05 & Has effect \\
2 & $\begin{array}{l}\text { Subjective Norm (SN) has an } \\
\text { influence on Perceived Ease of Use } \\
\text { (PEU) }\end{array}$ & 0,074 & 1.112 & 0,266 & 0,05 & $\begin{array}{c}\text { No } \\
\text { effect }\end{array}$ \\
3 & $\begin{array}{l}\text { Output Quality (OQ) has an } \\
\text { influence on Perceived Ease of Use } \\
\text { (PEU) }\end{array}$ & 0,652 & 6.984 & 0,000 & 0,05 & Has effect \\
4 & $\begin{array}{l}\text { Perceived Enjoyment (PE) has an } \\
\text { influence on Perceived Usefulness } \\
\text { (PU) }\end{array}$ & 0,245 & 4.301 & 0,000 & 0,05 & Has effect \\
5 & $\begin{array}{l}\text { Perceived Enjoyment (PE)has an } \\
\text { influence on Perceived Ease of Use } \\
\text { (PEU) }\end{array}$ & 0,103 & 1.453 & 0,146 & 0,05 & No effect \\
6 & $\begin{array}{l}\text { Perceived Ease of Use (PEU) has an } \\
\text { influence on Perceived Usefulness } \\
\text { (PU) }\end{array}$ & 0,628 & 8.997 & 0,000 & 0,05 & Has effect \\
$\begin{array}{l}\text { Perceived Usefulness (PU) has an } \\
\text { influence on the Intention to Use } \\
\text { (ITU) }\end{array}$ & 0,468 & 8.821 & 0,000 & 0,05 & Has effect \\
$\begin{array}{l}\text { Perceived Ease of Use (PEU) has an } \\
\text { influence on the Intention to Use } \\
\text { (ITU) }\end{array}$ & 0,247 & 4.668 & 0,000 & 0,05 & Has effect \\
$\begin{array}{l}\text { Intention to Use (ITU) has an } \\
\text { influence on CRM Technology } \\
\text { Adoptions }\end{array}$ & 1,021 & 10.687 & 0,000 & 0,05 & Has effect \\
\hline
\end{tabular}

From table 3, it can be concluded that the relationship between variables is in the following:

1. Subjective Norm for Perceived Usefulness

Estimation of regression values from coefficient parameters is 0.256 and C.R value is 4.501 . This indicates that the Subjective Norm with Perceived Usefulness is positive. Testing between these two variables gives a probability value of $0.000(\mathrm{p}<0.05)$, so that $(\mathrm{SN})$ has a significant influence on (PU).

2. Subjective Norm for Perceived Ease of Use

Estimation of regression values from coefficient parameters is 0.074 and the C.R value of 1.112 indicates that the Subjective Norm with Perceived Ease of Use has a positive value. Testing between the two variables gives a probability value of $0.266(\mathrm{p}<0.05)$, so that $(\mathrm{SN})$ does not have a significant effect on (PEU).

3. Output Quality for Perceived Ease of Use

Estimation of regression values from coefficient parameters is 0.652 and C.R 6.984 indicates that the relationship between Output Quality and Perceived Ease of Use has a positive value. Testing between these two variables shows a probability value of $0.000(\mathrm{p}<0.05)$, so that (OQ) has a significant influence (PEU).

4. Perceived Enjoyment for Perceived Useful

Estimation of the regression value of the coefficient parameter is 0.245 and the C.R value is 4.301 which indicates that the relationship between Perceived Enjoyment and Perceived 
Useful has a positive value. Testing between these two variables shows a probability value of $0.000(\mathrm{p}<0.05)$, so that (PE) has a significant influence on (PU).

5. Perceived Enjoyment for Perceived Ease of Use

Estimation of regression values from coefficient parameters is 0.103 and C.R value 1.453 shows that the relationship between Perceived Enjoyment and Perceived Ease of Use has a positive value. Testing between these two variables shows a probability value of 0.146 ( $p$ $<0.05$ ), so that (PE) has a significant effect on (PEU) not supported and can be stated not to have significant PE effect on PEU.

6. Perceived Ease of Use for Perceived Useful

Estimation of the regression value of the coefficient parameter is 0.628 and the C.R value is 8.997 which indicates that the relationship between Perceived Ease of Use and Perceived Useful has a positive value. Testing the relationship between these two variables shows a probability value of 0.000 ( $\mathrm{p}<0.05$ ), so that (PEU) has a significant effect on (PU).

7. Perceived Useful for Intention to Use

Estimation of regression values from coefficient parameters is 0.468 and C.R value is 8.821 with this indicating that the relationship between Perceived Useful and Intention to use has a positive value. Testing the relationship between these two variables shows a probability value of 0.000 ( $\mathrm{p}<0.05$ ) so that (PU) (ITU).

8. Perceived Ease of Use for Intention to Use

Estimation of regression values from coefficient parameters is 0.247 and C.R value is 4.668 which indicates that the Perceived Ease of Use relationship with Intention to Use has a positive value. Testing the relationship of these two variables shows a probability value of 0.000 ( $\mathrm{p}<0.05$ ), so that $(\mathrm{H} 8)$ which reads "Perceived Ease of Use (PEU) has a significant effect on the Intention to Use (ITU).

9. Intention to Use for CRM Technology Adoption

The estimated parameter of the standardized regression weight coefficient value is 1,021 C.R 10.687 which indicates that the relationship of Intention to Use with CRM Technology Adoption has a positive. Testing the relationship of these two variables shows a probability value of 0.000 ( $\mathrm{p}<0.05)$, so that (H9) which reads (PEU) has a significant effect on CRM Technology Adoption (CRM) (ITU) and can be declared supported and has an influence on Perceived Ease of Use with CRM Technology Adoption.

Based on the conclusions between the variables from table 3 explained before, the flowchart arrangement has been formed which has been acquired by the results of the hypothesis above, which can be seen in figure 7 .

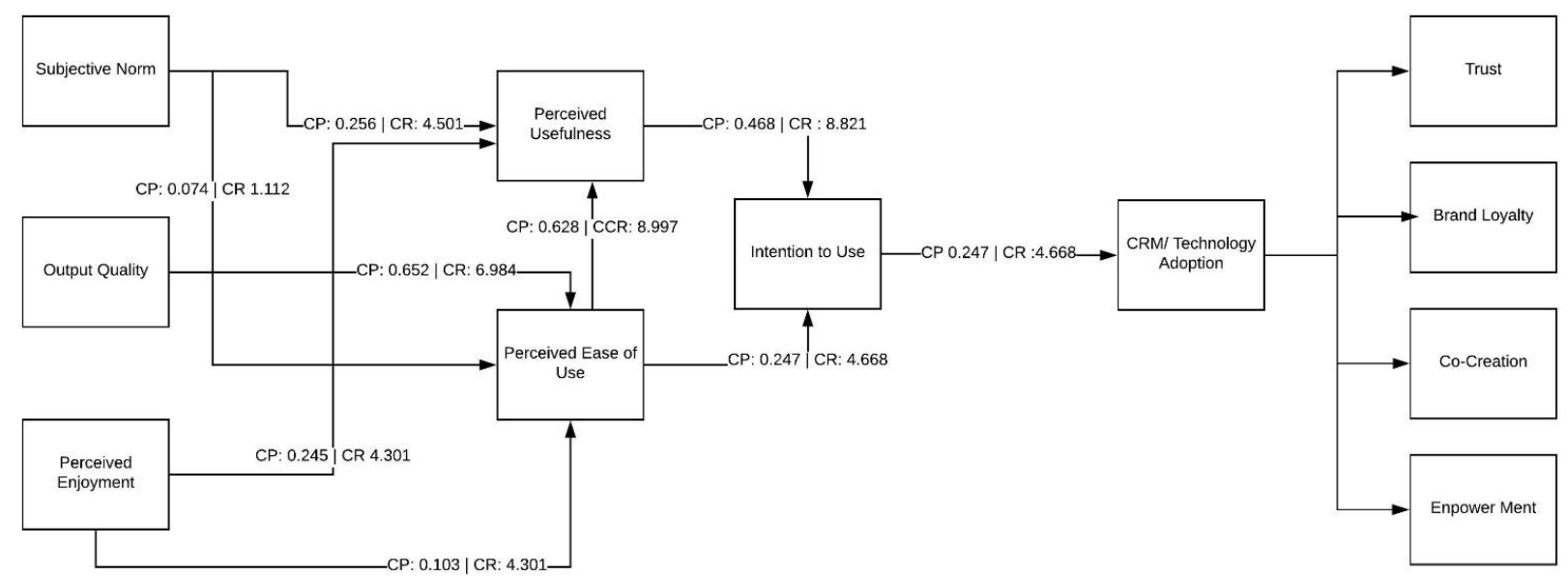

Figure 7. TAM Flowchart and CRM adoption based on the results of the hypothesis 


\subsection{Analysis}

4.4.1. Subjective Norm for Perceived Usefulness. The test results show that the Subjective Norm has a significant effect on Perceived Usefulness. Subjective norms in the acceptance process by customers at PT. Hasjrat Abadi affect the use of service systems with other customers at PT. Hasjrat Abadi. A customer can be tested whether he is willing to use an application system created by PT. Hasjrat Abadi. Every customer who has a purpose to do transaction can have good relationships with the company and get the satisfaction given by the company.

4.4.2. Subjective Norm for Perceived Ease of Use. The test results show that the Subjective Norm does not have a significant impact on Perceived Ease of Use. Variables that exist in the Subjective Norm will affect the ease and convenience of customers in using the application at PT. Hasjrat Abadi. A customer can influence other customers to use the application by providing ease of use and indirectly becoming mouth-to-mouth advertisers, so the company gets free endorse from the customer itself.

4.4.3. Output Quality for Perceived Ease of Use. The test results show that the Output Quality has a significant effect on Perceived Ease of Use. Venkatesh et al., stated that quality output is needed for development and direction in further quality searches [21]. The approach to measuring statistical output quality is to assess quality through the level of customer satisfaction with the products offered by the company to customers and can be seen from the intensity of customer use of the products provided by PT. Hasjrat Abadi.

4.4.4. Perceived Enjoyment for Perceived Usefulness. The test results show that the Perceived Enjoyment has a significant effect on Perceived Usefulness. Perceived Enjoyment is the extent to which the company's service to customers is considered to be very pleasant for the customer or not, aside from every consequence of performance resulting from the use of the application by the customer. Perceived Enjoyment in the services provided can be assessed from how much customers who use the application feel happy, comfortable and enjoy the application provided by PT. Hasjrat Abadi.

4.4.5. Perceived Enjoyment for Perceived Ease of Use. The test results show that the Perceived Enjoyment has no significant effect on Perceived Ease of Use. Perceived Enjoyment customers for applications are very useful in supporting customers to use an application more often, especially applications from PT Hasjrat Abadi. The more customers like the application, the more often the application is used. However, the customer does not have a significant influence on the usefulness of the application from PT. Hasjrat Abadi. Therefore the company must strive to create an application that is more convenient and user-friendly for customers.

4.4.6. Perceived Ease of Use for Perceived Usefulness. The test results show that the Perceived Ease of Use has a significant effect on Perceived Usefulness. Perceived Ease of Use where an application that will be used by customers can be easily used and does not make customers uncomfortable, and it is also apparent that the value of application use has a significant influence so that customers are very comfortable with the application and in the future other needs can be developed to satisfy customers.

4.4.7. Perceived Usefulness for Intention to Use. The test results show that Perceived Usefulness has a significant influence on the Intention to Use. The service system has been provided based on the interest of the customer and also influences the usefulness that can be seen from the use of the application. If the use of the system can provide benefits for customers in making payment transactions and product selection transactions, then the customer will feel comfortable with the services of PT. Hasjrat Abadi and at any time can use the application.

Ngangi, Santoso (Customer Acceptance Analysis of Customer Relationship Management (CRM) Systems in Automotive Company using Technology Acceptance Model (TAM) 2) 
4.4.8. Perceived Ease of Use for Intention to Use. The test results show that the Perceived Ease of Use has a significant influence on the Intention to Use. Perceived Ease of Use in increasing one's interest in using an application. The service system provided is very acceptable to the customers themselves as application users and if the customer is interested in using the service system, then the application is successful. Thus, the customer's interest in using the application can increase more than usual. Therefore, PT. Hasjrat Abadi can provide an application that is convenient to use so that it can attract more customers.

4.4.9. Intention to Use for CRM Technology Adoption. The test results show that the Intention to Use has a significant effect on CRM Technology Adoption. The intention of someone in using a new application is the intention or desire to try to use a new application. This was stated by Davis, et al, that the use of information systems has long been hypothesized because of the intention of the user to try the application that will be used [22]. The intention of using the application is mainly judged by how much the user intends to use an actual application related to user behavior. The better the intention of the customer in using the application is the better the usefulness will be. This influences the use of TAM information system technology for CRM systems. Good intentions from customers are increasingly influential in the use of these technologies.

4.4.10. TAM's contribution to CRM. With this it can be seen that TAM has been successfully entered into CRM at PT. Hasjrat Abadi, so that the elements of the new CRM factors can be seen below:

1. Trust

In the Trust side, it can be seen that the customer's intention after obtaining satisfaction from the services of PT. Hasjrat Abadi which is one of the main components of TAM is the usefulness of the customer from PT. Hasjrat Abadi by always trusting the product from PT. Hasjrat Abadi, which is so good quality and elegant.

2. Brand Loyalty

In terms of brand loyalty, it can be seen from the customer's comfort in the facilities provided by PT. Hasjrat Abadi, so that customers have the intention to market the brand from PT. Hasjrat Abadi orally and in writing.

3. Co-Creation

In terms of Co-creation itself, because the customer is very comfortable with the use of the products presented by PT. Hasjrat Abadi, then PT. Hasjrat Abadi can be very motivated to invest in new products for customers to enjoy by designing new models that are desired from customers.

4. Empowerment

In terms of empowerment, due to the ease and instant website of PT. Hasjrat Abadi, can be anywhere and anytime, so as to provide opportunities for customers to think, speak and act, through social media and other media, making it easier for companies to be faster and easier to serve customers.

\section{Conclusion}

Based on the results of the discussion and from the result on table 3 above, some conclusions can be drawn. After analyzing the data into AMOS and SEM analysis is done, the TAM model gets the following results:

1. Subjective Norm (SN) has a significant effect on Perceived Usefulness (PU) and has a $P$ value of 0.00 , which means that it has an effect on technology adoption, namely CRM.

2. Subjective Norm (SN) has a significant effect on Perceived Ease of Use (PEU) and has a P value of 0.266 , which means it has no effect on technology adoption, namely CRM so that this variable cannot be used.

3. Output Quality (OQ) has a significant effect on Perceived Ease of Use (PEU) and has a P value of 0.00 , which means that it has an effect on technology adoption, namely CRM. 
4. Perceived Enjoyment (PE) has a significant effect on Perceived Usefulness (PU) and has a $\mathrm{P}$ value of 0.00 , which means that it has an effect on technology adoption, namely CRM.

5. Perceived Enjoyment (PE) has a significant effect on Perceived Ease of Use (PEU) and has a $P$ value of 0.146 , which means that it has no effect on technology adoption, namely CRM.

6. Perceived Ease of Use (PEU) has a significant effect on Perceived Usefulness (PU) and has a $\mathrm{P}$ value of 0.00 , which means that it has an effect on technology adoption, namely CRM.

7. Perceived Usefulness (PU) has a significant effect on Intention to Use (ITU) and has a P value of 0.00 , which means that it has an effect on technology adoption, namely CRM.

8. Perceived Ease of Use (PEU) has a significant effect on Intention to Use (ITU) and has a P value of 0.00 , which means that it has an effect on technology adoption, namely CRM.

9. Intention to Use (ITU) has a significant effect on CRM and has a P value of 0.00 , which means that it has an effect on technology adoption, namely CRM.

Then it can be concluded based on 9 hypotheses above, 7 hypotheses are accepted and 2 hypotheses are not, so the TAM model has been successfully applied to the CRM model for PT. Hasjrat Abadi, which can be seen in terms of usefulness and ease of use which are components - the main component of TAM, can be interrelated with new components in CRM, namely Trust, Brand Loyalty, Cocreation, Empowerment so that PT. Hasjrat Abadi, can use the new models of CRM to encourage customer satisfaction and make new customer will arrive and try products from PT. Hasjrat Abadi.

From the results of the discussion portion, the writer has suggestions for the application of this study:

1. For companies

We hope that this study can be used as a reference in order to build rapport between customer and company and bring with it many benefits for the company.

2. For the Academic field

The study can be used for reference for any students that will perform research about information systems and TAM.

3. For future studies

Any future studies should focus on different and new areas/locations of research so that research and information into the effects of TAM (Technology acceptance model) and CRM technology adoption can be explored further, as well as the compilation of accurate information.

\section{References}

[1] W. E. Deming, Out of Crisis. Massachusetts: MIT Press, 1986.

[2] J. M. Juran and F. M. Gryna, Quality Control Handbook. New York: McGraw-Hill, 1988.

[3] P. B. Crosby, Quality is free: The art of making quality certain. 1979.

[4] David A. Garvin, Managing Quality: The Strategic and Competitive Edge. New York: The Free Press, 1988.

[5] J. Dean and J. Evan, Total Quality: Management organization and strategy. 1994.

[6] P. Gupta, S. Guha, and S. Krishnaswami, "Firm growth and its determinants," J. Innov. Entrep., p. 1, 2013.

[7] N. Almunawar, M and A. M, "Improving Customer Service in Healthcare," 2012.

[8] Wolfgang Grassl, "Business Models of Social Enterprise: A Design Approach to Hybridity," ACRN J. Entrep. Perspect., pp. 37-60, 2012.

[9] T. W. Jackson, "Personalisation and CRM," J. Database Mark. Cust. Strateg. Manag., 2007.

[10] V. Pal Dhaka and N. Pooja, "A Review: Benefits and Critical Factors of Customer Relationship Management," Int, J. Adv. Netw. Appl., pp. 2191-2194, 2014.

[11] K. C. Laudon and J. P. Laudon, "Management Information System: Managing Digital Firm," Int. J. Comput. Commun. Control, 2007.

[12] I. Krawczyk-Sokołowska and B. Ziołkowska, "Computer-Aided and Web-Based Tools in Customer Relationship Management," Acta Electrotech. Inform., vol. 13, no. 4, pp. 13-19,

Ngangi, Santoso (Customer Acceptance Analysis of Customer Relationship Management (CRM) Systems in Automotive Company using Technology Acceptance Model (TAM) 2) 
2013.

[13] F. D. Davis, "A technology acceptance model for empirically testing new end-user information systems: Theory and results," 1985.

[14] M. Fishbein and I. Ajzen, "Belief, Attitude, Intention and Behaviour: An Introduction to Theory and Research_ch3," Addison-Wesley Publishing Company. 1975.

[15] V. Venkatesh and F. D. Davis, "A Model of the Antecedents of Perceived Ease of Use: Development and Test," Decis. Sci., pp. 451-481, 1996.

[16] A. Ferdinand, Structural Equation Modelling dalam Penelitian Manajemen. Semarang: Universitas Diponegoro, 2002.

[17] Sugiyono, Statistika untuk Penelitian. Bandung: Alfabeta, 2014.

[18] V. Venkatesh and F. D. Davis, "A Theoretical Extension of the Technology Acceptance Model: Four Longitudinal Field Studies," Manage. Sci., pp. 186-204, 2000.

[19] S. S. Al-Gahtani and M. King, "Attitudes, satisfaction and usage: Factors contributing to each in the acceptance of information technology," Behav. Inf. Technol., pp. 277-297, 1999.

[20] I. Ghozali, "Model Persamaan Struktural. Konsep dan Aplikasi Dengan Program AMOS 22.0. Update Bayesian SEM," in Model Persamaan Struktural. Konsep dan Aplikasi Dengan Program AMOS 24. Update Bayesian SEM, 2014.

[21] V. Venkatesh and H. Bala, "Technology acceptance model 3 and a research agenda on interventions," Decis. Sci., pp. 273-315, 2008.

[22] F. D. Davis, "Perceived Usefulness, Perceived Ease of Use, and User Acceptance of Information Technology," MIS Q., pp. 319-340, 1989. 